УДК 343.131 .7

DOI https://doi.org/10.51989/NUL.2021.6.24

\title{
КОНСТИТУЦІЙНО-ПРАВОВИЙ ЗМІСТ ПРЕЗУМПЦІЇ НЕВИНУВАТОСТІ
}

\author{
Дуюнова Тетяна Василівна,
}

кандидат юридичних наук, доктор економічних наук, доцент кафедри публічного та приватного права

Державного біотехнологічного університету

\section{Півненко Людмила Володимирівна,}

старший викладач кафедри публічного та приватного права Державного біотехнологічного університету

У статті досліджено поняття та зміст основоположного конституційного принципу презумпції невинуватості. Визначено його місце та роль у сфері кримінального судочинства. Зазначено, що принцип презумпції невинуватості - це закріплена у Конституції України й у Кримінальному процесуальному кодексі України правова гарантія, яка виступає запобіжником формування передчасної обвинувальної позиції у суб'єктів кримінального процесу. Презумпція невинуватості розглядається як один із базових демократичних принципів кримінального процесу, що має самостійне значення та виконує роль «захисного механізму» від незаконних дій державних органів і посадових осіб, котрі ведуть кримінальний процес. Структурними елементами презумпції невинуватості виступають: правило про недопустимість доказів; правило про обов'язок доведення вини; норми, що забезпечують свободу оскарження в апеляційному та касаційному порядку вироку та інших судових рішень; правило про відшкодування матеріальної та моральної шкоди, завданої безпідставним засудженням.

Зазначено, що належна реалізація принципу презумпції невинуватості спряє виконанню завдань кримінального судочинства у сфері охорони прав учасників кримінального провадження, а також забезпечення швидкого, повного та неупередженого розслідування і судового розгляду з тим, щоб кожний, хто вчинив кримінальне правопорушення, був притягнутий до відповідальності в міру своєї вини, жоден невинуватий не був обвинувачений або засуджений. Презумпція невинуватості забезпечує право особи, щодо якої сформульовано обвинувачення, на незалежний і безсторонній суд, оскільки є одним із елементів справедливого судового розгляду.

Ключові слова: кримінальний процес, принципи кримінального процесу, підозрюваний, обвинувачений, справедливий суд, презумпція невинуватості.

\section{Duiunova Tatiana, Pivnenko Liudmyla. Constitutionally-legal maintenances of presumption of innocence}

A concept and maintenance of fundamental constitutional principle of presumption of innocence are investigational in this article. His location and role are determined in the field of criminal trial. It is marked that principle of presumption of innocence it envisaged in Constitution of Ukraine and in the Criminal judicial code of Ukraine legal guarantee that comes forward as a safety device of forming of premature accusatory position for the subjects of criminal procedure. Principle of presumption of innocence is examined, as one of base democratic principles of criminal procedure that has an independent value, and executes here the role of "nocifensor" from the illegal actions of public organs and public servants that conduct criminal procedure. As structural elements of presumption of innocence come forward : governed about impermissibility of proofs; governed about the duty of leading to of guilt; governed about the compensation of the material and moral harm inflicted by groundless conviction.

It is marked that the proper realization of principle of presumption of innocence assists implementation of tasks of criminal trial, in the field of guard of rights for the participants of criminal procedure, and also providing of rapid, complete and investigation and judicial trial with that each, who accomplished criminal offence, was brought to the account to the extent of the guilt, the not a single guilty was accused or convict. Presumption of innocence provides a right for personality in relation to that a prosecution is set forth, on an independent and impartial court, as is one of elements of the fair judicial hearing.

Key words: criminal process, principles of criminal process, is suspected, defendant, just court, presumption of unguiltiness. 
у складних умовах сьогодення, що супроводжуються політичною, економічною, соціальною кризами, військовим конфліктом на сході нашої держави, Україна все ж таки обрала шлях незалежного розвитку, який закріпила на конституційному рівні, підтвердивши своє прагнення розвивати та зміцнювати демократичну, соціальну, правову державу, одним із основних принципів якої $\epsilon$ забезпечення прав і свобод людини. В Основному законі нашої держави закладено принципово нові правові парадигми зовнішньої та внутрішньої політики України, спрямовані на утвердження та забезпечення прав і свобод людини. Обов'язок держави забезпечувати права людини виступає як головна домінанта Конституції. Найбільш актуальними питання забезпечення прав людини у сучасній теорії та практиці правозастосування стають у кримінальному судочинстві. Насамперед це пов'язано із тим, що у сфері кримінальнопроцесуальної діяльності виникають і проявляються найбільш суттєві обмеження конституційних прав людини. Державні органи та посадові особи, котрі ведуть кримінальний процес, можуть застосовувати заходи примусу до інших учасників (затримання, тримання під вартою, відсторонення від посади тощо). Отже, за такого стану речей стає очевидним, що проголошення людини найвищою соціальною цінністю та закріплення у Конституції ії основних прав і свобод без реальних гарантій їх здійснення у рамках кримінального процесу не мають ніякого значення. Права, якими наділені учасники кримінального провадження, не можуть самі по собі автоматично забезпечити власне існування, а отже, процес забезпечення прав людини у кримінальному процесі пов'язаний зі створенням процесуальних гарантій щодо їх реалізації. Однією із таких гарантій $€$ конституційний принцип презумпції невинуватості.

Питання, що стосуються сутності та змісту принципу презумпції невинуватості, особливостей його реалізації у сфері кримінально-процесуальної діяльності, були і залишаються вкрай актуальними та привертають увагу як науковців, так і правознавців-практиків. Зокрема, дослідженням вказаних питань займалися
Г.І. Барчук, Ю.В. Баулін, О.А. Бунтовська, В.В. Вапнярчук, П.П. Захарченко, В.Т. Нор, В.В. Крижанівський, В.О. Попелюшко, Т.І. Фулей, П.Ю. Чеханюк, Г.Ю. Юдківська та ін.

Незважаючи на значні наукові доробки вчених, проблемні аспекти реалізації принципу презумпції невинуватості досі не втрачають актуальності. Це пов'язано із тим, що практика правозастосування, пристосувавшись до нових правил кримінального провадження, водночас зберегла старі пріоритети та методи роботи, коли у процесі досудового розслідування та судового розгляду зберігається можливість порушення основних принципів забезпечення прав людини, зокрема презумпції невинуватості. Це означає, що навіть належне законодавче закріплення презумпції невинуватості як одного з основоположних принципів кримінального провадження не означає автоматичної реалізації як самої презумпції, так і пов'язаних із нею правових положень. Аналізуючи вище викладене, можна констатувати, що розуміння сутності та змісту презумпції невинуватості потребує постійного моніторингу законодавства та подальших ґрунтовних наукових досліджень у царині забезпечення прав людини у кримінальному судочинстві.

Метою статті $\epsilon$ дослідження сутності та змісту принципу презумпції невинуватості, визначення його місця та ролі у сфері кримінального судочинства.

Презумпція невинуватості особи, яка підозрюється або обвинувачується у вчиненні кримінального правопорушення, $\epsilon$ конституційним принципом в Україні та загальновизнаним принципом міжнародного права, реалізований у сучасному законодавстві майже усіх демократичних країн світу. Вважається, що вперше презумпція невинуватості була закріплена у французькій Декларації прав людини та громадянина (1789р.) і сформульована таким чином: «Оскільки кожна людина припускається невинуватою, доки її не оголосять винуватою (судом), то у разі необхідності їі арешту будь-яка надмірна строгість, не зумовлена необхідністю, повинна суворо каратися законом» [1, с. 80].

Сьогодні принцип презумпції невинуватості закріплений у численних 
міжнародно-правових актах, а саме: у ч. 1 ст. 11 Загальної декларації прав людини; у п. 2 ст. 14 Міжнародного пакту про громадянські та політичні права; у п. 2 ст. 6 Конвенції про захист прав людини й основоположних свобод тощо. Це означає, що принцип презумпції невинуватості розглядається як один із базових демократичних принципів кримінального судочинства, який має міжнародний характер, має самостійне значення та виконує роль «захисного механізму» від незаконних дій державних органів і посадових осіб, котрі ведуть кримінальний процес, незаконного засудження та передчасних суб'єктивних висновків як учасників кримінального провадження, так і суспільства загалом.

у системі національного законодавства принцип презумпції невинуватості $\epsilon$ порівняно новим, і його поява зумовлена прийняттям Конституції України 1996 р. Ст. 62 Конституції України та ст. 17 Кримінального процесуального кодексу України містять положення, відповідно до яких особа вважається невинуватою у вчиненні кримінального правопорушення і не може бути піддана кримінальному покаранню, доки її вину не буде доведено у порядку, передбаченому Кодексом, і встановлено обвинувальним вироком суду, що набрав законної сили. Ніхто не зобов'язаний доводити свою невинуватість у вчиненні кримінального правопорушення та має бути виправданим, якщо сторона обвинувачення не доведе винуватість особи поза розумним сумнівом [2].

Незважаючи на досконале нормативноправове визначення принципу презумпції невинуватості як у національному, так і в міжнародному законодавстві, у юридичній доктрині відсутня єдність поглядів науковців на сутність і зміст цього принципу, його місце та роль у кримінальному судочинстві.

Сам термін «презумпція» (від лат. «praesumptio») походить від слова «praesumere» (з лат. - передбачати, передчувати, вгадувати) й у перекладі з латинської мови означає припущення [3, с. 704]. Юридична енциклопедія за редакцією Ю.С. Шемшученка містить загальне визначення правових презумцій: «Презумпції у праві - це закріплені правовими нормами припущення про вірогідність настання певного юридичного факту» [4, с. 71]. Вивчаючи загальні характеристики правових презумпцій і їх значення для кримінального процесуального доказування, В.В. Вапнярчук вказу, що правова презумпція - це закріплене (прямо або непрямо) у нормах права ймовірне бездоказове припущення про наявність або відсутність фактів (звідси й друга назва - факти, що презюмуються), які можуть призводити до певних наслідків у сфері правового регулювання, що повинно обов'язково реалізовуватися у конкретній юридичній ситуації та $\epsilon$ значущим у разі його спростування [5, с. 65].

Досліджуючи презумпцію невинуватості як різновид правової презумпції, науковці інтерпретують різне бачення ії̈ сутності, змісту та навіть сфери реалізації. Наприклад, Г.Ю. Юдківська стверджує, що презумпція невинуватості - це міжгалузевий принцип, який діє у тих галузях права, котрі визначають процедуру встановлення винуватості особи у скоєнні правопорушення та залучення ії̈ до юридичної відповідальності. Дослідниця зазначає, що, оскільки у процесі і кримінального, й адміністративного, і дисциплінарного провадження здійснюється доказування винуватості особи у скоєнні протиправного діяння, то, відповідно, обґрунтовується питання застосування до винуватого відповідної юридичної санкції [6, с. 19].

Аналіз нормативного змісту принципу презумпції невинуватості дає змогу стверджувати, що сфера його реалізації - це кримінальне судочинство. Очевидно, що етимологічно поняття «винуватість», «вина» пов'язані з діяннями, визначеними Кримінальним кодексом України як кримінальні правопорушення. Саме поняття «невинуватість» $\epsilon$ похідним від «винуватість», а отже, за відсутності самої події кримінального правопорушення, без особи потерпілого, без завдання фізичної, матеріальної чи моральної шкоди, не виникає питання про винуватість особи, а відповідно, і про невинуватість. Принцип презумпції невинуватості діє на усіх стадіях кримінального процесу, забезпечуючи підозрюваному або обвинуваченому гідне ставлення до нього як до особи, котра $\epsilon$ не винуватою у вчиненні кримінального правопорушення, допоки зворотне не буде 
доведено у законному порядку та встановлено обвинувальним вироком суду, що набрав законної сили.

Розглядаючи презумпцію невинуватості та їі роль у кримінальному процесі, П.П. Захарченко стверджує, що сутність презумпції невинуватості полягає у тому, що особа, стосовно якої проводяться процесуальні та слідчі дії з боку суб'єктів, які здійснюють функцію обвинувачення, уважається невинуватою. На думку науковця, цей принцип не лише вважається формальною вимогою, а й $\in$ одночасно основною кримінально-процесуальною гарантією [7, с. 67].

За твердженням T.I. Фулей, презумпція невинуватості $€$ одним із елементів справедливого судового розгляду. Цей принцип забороняє формування передчасної позиції суду, яка би відображала думку про те, що особа, обвинувачена у вчиненні злочину, $є$ винуватою ще до того, коли ії вина буде доведена відповідно до закону. Захисна функція реалізується через покладання тягаря доведення на сторону обвинувачення, тобто виявляється у звільненні особи від обов'язку, водночас у наданні їй права брати участь у доказуванні, у тому числі і своєї невинуватості [8, с. 47].

Деякі науковці вбачають зміст принципу презумпції невинуватості у забезпеченні швидкого розслідування та судового розгляду з тим, щоб кожний, хто вчинив злочин, був притягнутий до відповідальності у міру своєї вини, жоден невинуватий не був обвинувачений або засуджений, жодна особа не була піддана необґрунтованому процесуальному примусу і щоб до кожного учасника кримінального провадження була застосована належна правова процедура [9, с. 327].

Варто погодитися із Г.І. Барчуком, котрий вдало і найбільш повно визначив сутність презумпції невинуватості. Дослідник зазначає: «Основна суть презумпції невинуватості полягає у тому, що будь-яке висунуте проти особи обвинувачення має бути доведено, і тільки внаслідок судового розгляду з його гласністю, змагальністю, безпосередністю дослідження доказів та іншими гарантіями особа може бути визнана винною у вчинені злочину, доти вона вважається невинуватою». Науковець наголошує на тому, що у презумпції невинуватості виражена ідея про судовий контроль за правильністю висновків органів розслідування та прокурора з питання про винуватість особи у вчиненні злочину [10, с. 54].

Структурними елементами презумпції невинуватості виступають: правило про недопустимість доказів; правило про обов'язок доведення вини; норми, що забезпечують свободу оскарження в апеляційному та касаційному порядку вироку та інших судових рішень; правило про відшкодування матеріальної та моральної шкоди, завданої безпідставним засудженням.

Узагальнення наукових позицій вчених щодо змісту та сутності принципу «презумпції невинуватості» дає змогу стверджувати, що здебільшого вона розглядається як закріплена на конституційному рівні правова гарантія, яка не допускає формування передчасної позиції щодо винуватості особи у вчиненні кримінального правопорушення доти, доки їі вину не буде доведено у встановленому кримінальним процесуальним законом порядку і підтверджено обвинувальним вироком суду, який набрав законної сили. Це означає, що поводження з особою, вина якої у вчиненні кримінального правопорушення не встановлена обвинувальним вироком суду, що набрав законної сили, має відповідати поводженню з невинуватою особою. До набрання обвинувальним вироком суду законної сили не допустимо стверджувати про таку вину публічно, у тому числі у засобах масової інформації.

Як справедливо зазначає В.Т. Нор, призначення презумпції невинуватості насамперед полягає у протистоянні у кримінальному судочинстві обвинувальному ухилу, суб'єктивізму, тенденційності чи навіть свавіллю всьому, що перетворює кримінальне судочинство у знаряддя розправи над обвинуваченим, ототожнює обвинуваченого з винуватим, робить його фактично безправним [11, с. 26].

Принцип презумпції невинуватості насамперед адресований державним органам і посадовим особам, котрі ведуть кримінальний процес і на котрих законодавчо покладається обов'язок доказування. Це означає, що слідчий, прокурор, органи дізнання повинні відстояти свою правову позицію шляхом проведення процесуальних дій, спрямованих на формування 
обвинувальної доказової бази та на ії обґрунтування у процесуальних рішеннях. Таким чином держава гарантує, що вина особи (підозрюваного, обвинуваченого) буде доведена або спростована у межах процесуального закону належними, неспростовними доказами.

Аналізуючи вищевикладене, можна констатувати, що принцип презумпції невинуватості - це закріплена у Конституції України й у Кримінальному процесуальному кодексі України правова гарантія, яка виступає запобіжником формування передчасної обвинувальної позиції у суб'єктів кримінального процесу, а саме у слідчого прокурора, слідчого судді й у суспільства загалом щодо винуватості підозрюваного, обвинуваченого, доки їх вина не буде доведена у змагальному судовому процесі, обвинувальним вироком суду, що набрав законної сили. Презумпція невинуватості слугує запорукою гарантій у кожному кримінальному провадженні. Ії̈ суть полягає у тому, що будь-яке висунуте проти особи обвинувачення має бути обґрунтоване та надійно доведене. Структурними елементами презумпції невинуватості виступають: правило про недопустимість доказів; правило про обов'язок доведення вини; норми, що забезпечують свободу оскарження в апеляційному та касаційному порядку вироку та інших судових рішень; правило про відшкодування матеріальної та моральної шкоди, завданої безпідставним засудженням.

Належна реалізація принципу презумпції невинуватості сприяє виконанню завдань кримінального судочинства у сфері охорони прав учасників кримінального провадження, а також забезпечення швидкого, повного та неупередженого розслідування і судового розгляду з тим, щоб кожний, хто вчинив кримінальне правопорушення, був притягнутий до відповідальності у міру своєї вини, жоден невинуватий не був обвинувачений або засуджений. Презумпція невинуватості забезпечує також право особи, щодо якої сформульовано обвинувачення, на незалежний і безсторонній суд, оскільки принцип презумпції невинуватості $€$ одним із елементів справедливого судового розгляду. 3 огляду на актуальність досліджуваного питання виникає наукова та практична потреба подальшого поглибленого вивчення й аналізу проблемних аспектів реалізації принципу презумпції невинуватості у кримінальному судочинстві.

\section{ЛITEPATУPA:}

1. Попелюшко В.О. Презумпція невинуватості за законом на грані закону та поза його межами. Часопис Академії адвокатури України. 2008. № 1 (1). С. 78-82.

2. Кримінальний процесуальний кодекс України : Закон України від 13 квітня 2012 р. № 4651-VI. URL: https://zakon.rada. gov.ua/laws.

3. Великий енциклопедичний юридичний словник / за ред. Ю.С. Шемшученка. Київ : Юридична думка, 2007. 992 с.

4. Юридична енциклопедія : в 6 т. / редкол. : Ю.С. Шемшученко та ін. НАН України. Ін-т держави і права ім. В.М. Корецького НАН України. Київ : Українська енциклопедія ім. М.П. Бажана, 2003. Т. 5. 735 с.

5. Вапнярчук В.В. Загальна характеристика правових презумпцій та їх значення для кримінального процесуального доказування. Юрист України. № 3 (24). 2013. С. 62-68.

6. Юдківська Г.Ю. Презумпція невинуватості в кримінальному процесі України та практиці Європейського суду з прав людини : автореф. дис. ... канд. юрид. наук. Київ, 2008. 19 с.

7. Захарченко П.П., Махначова Н.М. Роль презумпції невинуватості у кримінальному процесі: витоки та сучасність. Право і держава сучасної України: проблеми розвитку та взаємодії. Київ, 2008. Ч. 2. 216 с.

8. Фулей Т. Презумпція невинуватості: концептуальні підходи. Слово Національної школи суддів України. 2012. № 1. С. 39-53.

9. Бунтовська О.А. Діяльність міліції України у процесі забезпечення реалізації конституційного принципу презумпції невинуватості. Науковий вісник Національної академії внутрішніх справ. 2013. № 2. С. 326-333.

10. Барчук Г.І., Чеханюк П.Ю. Презумпція невинуватості як один із принципів кримінального процесу. Науковий вісник Київського національного університету внутрішніх справ. 2010. № 4 (71). С. 54-62.

11. Нор В.Т. Презумпція невинуватості як конституційна засада кримінального судочинства та ії застосування в практиці Європейського Суду з прав людини. Часопис Національного університету «Острозька академія». Серія «Право». 2011. № 1 (3). С. 1-34. 